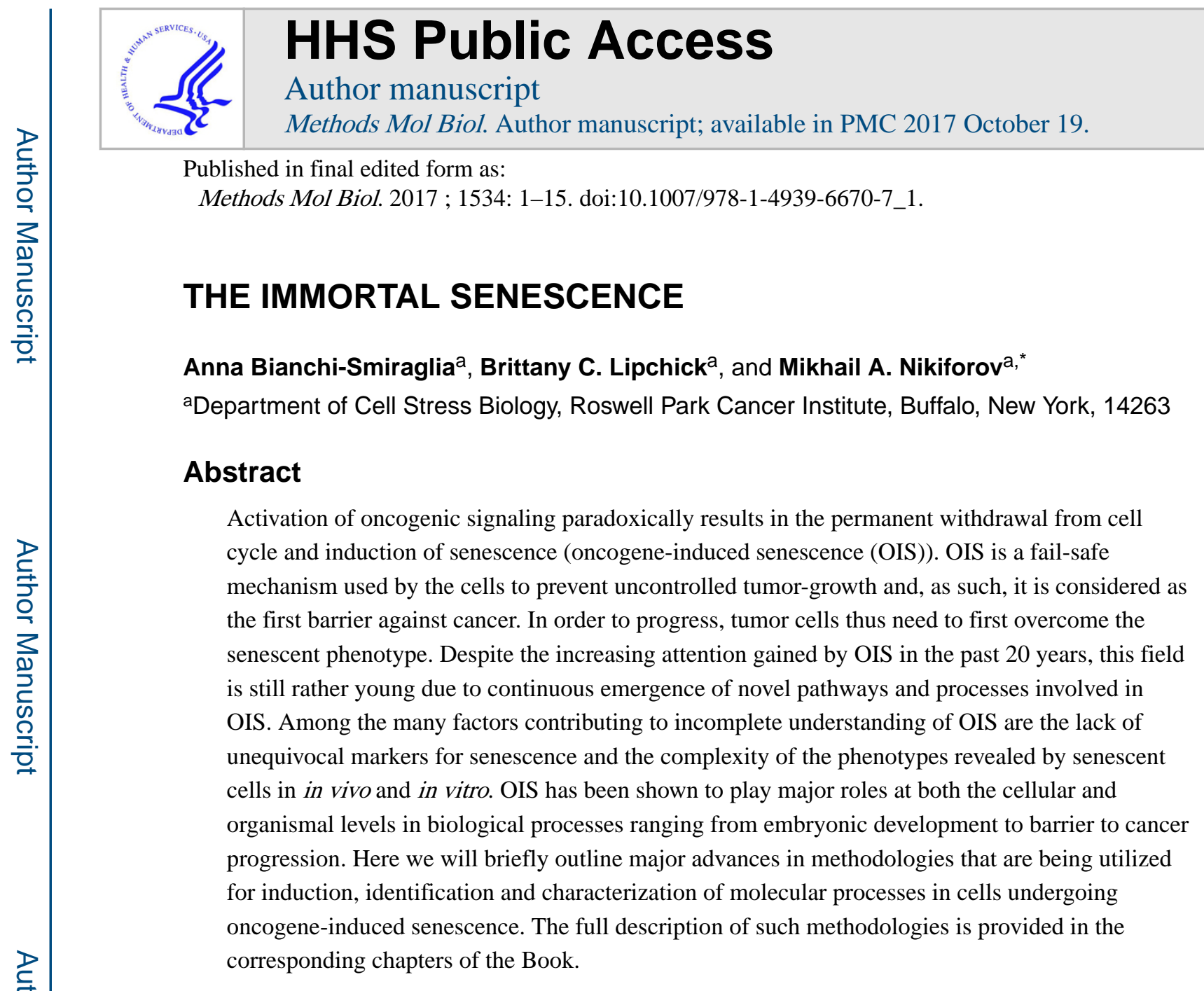

\title{
Introduction
}

Senescence is defined as an irreversible state of withdrawal from the cell cycle, which can be induced by either physiological signaling (replicative senescence) or aberrant activation of proliferative stimuli (1-5). Despite the lack of active proliferation, senescent cells remain highly metabolically active and are able to influence their environment, thereby modulating both physiological and pathological conditions (6-10).

It is well established that cultured cells have a limited lifespan and can replicate only a determined number of times (the so-called Hayflick limit (11)) before undergoing senescence. Upon activation of the senescent program, cells irreversibly exit the cell cycle and become unresponsive to the action of mitogens. Furthermore, senescent cells undergo morphological and metabolic alterations which lead to enlarged cell and organelles size, senescence-associated $\beta$-galactosidase activity, and secretion of extracellular matrix (ECM)degrading enzymes $(12,13)$. Many intrinsic cellular factors can contribute to the induction of senescence, which include telomeres shortening, DNA damage, mitochondrial dysfunctions (for comprehensive reviews see $\operatorname{Ref}(14,15)$ ), and, more recently, microRNAdriven regulatory mechanisms (16-19). Additionally, a few extrinsic factors have been

"Corresponding author: Mikhail A. Nikiforov, Department of Cell Stress Biology, Roswell Park Cancer Institute, BLSC L3-317, Buffalo, New York, 14263, Phone: (716) 845-3374, Fax: (716) 845-3944, mikhail.nikiforov@ roswellpark.org. 
implicated in the establishment/support of the senescent phenotype; these include the matricellular protein CCN1 (also known as CYR61) (20) and other ECM-related components such as integrin $\beta 1$ (21) and plasminogen-inhibitor-1 (PAI-1) (22), and secreted factors such as insulin-like growth factor binding proteins (IGFBPs) (23) and interleukin-6 (IL-6) (reviewed in Ref (24)). These observations indicate that senescence is not just dictated by events happening inside the cell but reflects also the integration of cues coming from the cell microenvironment.

Oncogene activation and the resulting aberrant proliferation induce another form of senescence called oncogene-induced senescence (OIS), which is considered one of the first barriers against tumor development (1, 3, 25-28). In many cases, OIS arises once cellular damage is ineffectively dealt with and unrepaired.

\section{OIS Induction}

Several cellular models are available to study oncogene-induced senescence, of which the most common is the either constitutive or inducible over-expression of an active form of HRAS (HRAS ${ }^{\mathrm{V} 12}$ ) in human diploid fibroblasts (29-31). With this method, cells become senescent within a week (29) and can be used for investigating senescence markers and phenotypes, as well as the development of screening for the identification of small molecules that can modulate OIS (32).

Intriguingly, OIS can be induced in tumor cells which presumably have already overcome senescence in the course of tumor progression. For instance, depletion of C-MYC to the levels detected in normal melanocytes was found sufficient to induce senescence in several melanoma cell lines $(33,34)$. Additionally, sustained expression of $\mathrm{p} 21^{\mathrm{WAF} 1 / \mathrm{CIP} 1}$ a p53dependent tumor suppressor gene has been shown to induce senescence in HT1080 fibrosarcoma cells (35). These models carry a high impact as reactivation of OIS in cancer has been recently proposed as a novel mean of therapeutic approach $(3,36-38)$.

A contentious topic in OIS revolves around the role played by two major tumor suppressors $\mathrm{p} 53$ (TP53) and $\mathrm{p} 16^{\mathrm{INK} 4 \mathrm{a}}$ (INK4a/ARF locus). Studies performed both in vitro and in transgenic mice have demonstrated that both proteins actively implement the OIS program in murine systems (39-45). However, their role in OIS in human cells is much less defined and seems to be cell type-dependent. In fact, while p53 depletion is required for the proliferation of human fibroblast expressing constitutive active $\operatorname{HRAS}(2,31,46,47)$, it is instead dispensable for senescence induction in human melanocytes $(33,48)$, keratinocytes (49), and mammary epithelial cells (50). Using primary melanocytes as a model system, it has been recently shown that the $\mathrm{RB} / \mathrm{p} 16^{\mathrm{INK} 4 \mathrm{a}}$ pathway regulates cell senescence in part through induction of histone deacetylase 1 (HDAC1)-mediated chromatin remodeling (51) and other studies similarly showed p16 $6^{\mathrm{INK} 4 \mathrm{a}}$ to be essential for RAS-mediated OIS in human cells (52, 53). However, other groups have reported discordant results in which p16 depletion had no effect on RAS (both N-RAS and H-RAS)-induced senescence in human melanocytes (1, 3, $33,54)$. 
Not only proteins but also micro RNAs (miRNAs) have been widely implicated in the control of OIS. miRNAs comprise a class of fairly recently discovered small non-coding RNAs that have been shown to control gene expression through induction of mRNA degradation or suppression of its translation (55-59). Depending on the targets and context, miRNAs can work as either tumor suppressors or oncogenes, and their expression patterns have been shown to significantly change during physiological and disease conditions, including cancer and senescence (55-59). In recent years, several miRNAs families have been reported to either favor (i.e. the miR17-20a and the miR-106b family (60-62)) or oppose (i.e. miR34a and miR22 $(63,64))$ OIS. Some of the mechanisms underlying these effects include suppression of the cell cycle inhibitor $\mathrm{p} 21^{\mathrm{WAF} 1 / \mathrm{CIP} 1}(60,62)$ and suppression of the C-MYC oncogene (63). Additionally, miRNAs have been shown to downregulate other important cell cycle promoters such as SIRT1 (a direct modulator of the p16-Rb and p53 pathways (65-67)), Sp1 (a transcription factor regulating the expression of p53 and many other genes involved in cell cycle $(68,69)$ ), and CDK6 (which phosphorylates pRb to delay senescence $(70,71))(64)$.

Additionally, a novel class of small non-coding RNAs called circularRNAs (cirRNAs) has been recently identified. CircRNAs functions are not well understood, however it has been shown that they can interact with several molecules of miRNA at a time, acting like "sponges" to reduce miRNA availability (72-75). The use of genome-wide miRNA and circRNA screenings emerges as an important tool for the identification of additional players involved in either the establishment of oncogene-induced senescence or facilitating its bypass $(60,76-78)$.

\section{Metabolic Changes Detected During OIS}

While the definition of OIS is well established, its phenotypical characterization suffers from the lack of unambiguous markers (79-81). Therefore, OIS detection necessitates the use of a combinatorial approach with multiple markers, highlighting the need for improved methodologies (80).

One of the most classical senescence detection assays is based on the activation status of senescence-associated $\beta$-galactosidase (SA- $\beta$-gal), an enzyme that normally resides in the lysosomes and is up-regulated in senescent cells. SA- $\beta$-gal activity is detected at suboptimal pH (pH 6.0) using either a chromogenic (5-bromo-4chloro-3-indolyls $\beta$-Dgalactopyranoside, X-Gal) (12) or a fluorescent substrate (fluorescin-di-Dgalactopyranoside, FDG) (82). However, SA- $\beta$-gal activity can be influenced by a plethora of other stimuli and therefore displays a high frequency of false positive results $(12,80,83$, 84). Moreover, while SA- $\beta$-gal staining can be performed on frozen samples, it cannot be used on fixed samples, thereby limiting its applicability in vivo (80). To this end, an improved Sudan Black B (SBB) histochemical stain has been recently described for detection of lipofuscin (an auto-fluorescent aggregate of oxidized proteins often found in both aged and senescent tissues $(85,86))$. In a parallel comparison with SA- $\beta$-gal staining, the improved SBB has shown promising results for the accurate detection of senescent cells in culture, as well as it revealed superior ability to detect senescent cells in tissue samples, including paraffin-embedded materials, extending its applicability (87). 
Another well-characterized aspect of senescence is the secretion of a distinct subset of cytokines and factors, collectively named the senescence-associated secretory phenotype (SASP) (88). The SASP has been shown to exert paracrine interactions to modulate the reinforcement and/or propagation of the senescent status $(8-10,89)$. Some of the key players which are induced by and in turn sustain and propagate the senescence phenotype belong to the family of the interleukins (especially the pro-inflammatory IL6 and IL1, as well as IL8) $(8-10,89,90)$. In addition, components of the tumor growth factor (TGF)- $\beta$ and insulin-like growth factor (IGF)/IGF receptor pathways have shown to play a prominent role in the SASP $(8-10,89,90)$. However, it is important to note that the full composition and effectors of the SASP is strongly influenced by the type of model system used (6). Additionally, depending on the cellular context, the SASP has been shown to have either pro-tumorigenic or tumor suppressor functions (7). Classically, the SASP is identified through ELISA or qRT-PCR assay for some of its major components; however, more recently a novel approach based on widefield high-content microscopy has been reported (90). This method allows for automatic acquisition and quantitative analysis of SASP makers in a 96-well format which is suitable for development of high-throughput systems for the identification of SASP-(and therefore OIS-) modifying agents.

DNA damage is one of the main inducers of senescence. In the context of OIS the DNA damage was believed to be caused mainly by reactive oxygen species (ROS) induction (91, 92) and the hyper-replication of genomic DNA i.e. multiple firing of the same replication origin (47). Another source of DNA damage in cells undergoing OIS originates from dysfunctional telomeres. Although telomere erosion is classically associated with replicative senescence, recent studies have shown that OIS can result in dysfunctional telomeres associated with DNA damage (telomere dysfunction-induced DNA damage foci, TIF) (93). TIF elicit the same DNA damage response (DDR) as non-telomeric lesions; however, while non-telomeric DDR foci get repaired over time, TIF are persistent and have been detected in vivo in pre-malignant lesions (93-95).

Recently, we and others highlighted a novel mechanism by which DNA damage is induced in cells undergoing OIS. It has been shown that activated HRAS signaling suppresses levels of key deoxyribonucleoside biosynthesis enzymes including thymidylate synthase (TS) and subunits of ribonucleotide reductase (RRM1 and RRM2) $(96,97)$. This results in depletion of cellular dNTP pools which in conjunction with HRAS-induced DNA polymerase activity results in severe DNA damage $(96,97)$. Interestingly, TS, RRM1 and RRM2 have been verified as bona fide targets of C-MYC (96, 98-100). Consistently, ectopic expression of CMYC has been shown to increase the intracellular nucleotide pools (99-101), and to suppress oncogene-induced senescence in normal and transformed human melanocytic cells $(33,98)$. In support of the role of nucleotide levels in control of OIS, it has been shown that supplementation with deoxyribonucleotides or ectopic expression of enzymes involved in their biosynthesis (TS, RRM1, RRM2) was sufficient to bypass the senescent phenotype induced by either overexpression of oncogenic RAS (H-RAS) in normal cells $(96,97)$ or by depletion of C-MYC in melanoma cells (98). Therefore, intracellular dNTP levels emerge as important modulators of DNA damage and OIS in normal and transformed cells. 
The changes described above are just a fraction of a larger scale metabolic alterations occurring in cells undergoing OIS, and the global metabolic changes occurring during oncogene-induced senescence have been the focus of study of several groups (102-106). Some of the other pathways altered during OIS include the oxidation of fatty acids (103), glucose metabolism (6), mitochondrial oxygen consumption (103), as well as protein ubiquitination (106).

OIS-undergoing cells present with a distinct signature of metabolites compared to cells that experienced replicative senescence, including decreased lipid synthesis as well as increased fatty acid oxidation due to increased levels of inactive acetyl-CoA carboxylase 1 (ACC1) (103). Cells undergoing OIS also display a high basal rate of oxygen consumption, which is a major reason for the above-mentioned increase in fatty acid oxidation concomitant with no increase in mitochondrial uncoupling (103).

Ubiquitination is a common post-translational modification (PTM), which can either direct proteins for degradation through the $26 \mathrm{~S}$ proteasome system (polyubiqutination) or can alter a protein function (monoubiquitination) $(107,108)$. The process of ubiquitination is highly dynamic, being regulated by both ubiquitin ligases (E1, E2, and E3 enzymes) which add ubiquitin moieties to proteins, and deubiquitinating enzymes (DUBs) which instead remove the tag (109). A recent paper profiled the changes in protein ubiquitination patterns occurring during OIS and identified most of the alterations being clustered within the mammalian target of rapamycin (mTOR) downstream effectors pathways: 4EBP-EIF4E, p70S6K and EEF2K/EIF2 (106). These pathway plays a prominent role in the translational control of cell growth and proliferation (110).

mTOR is also critical for the regulation of autophagy, a tightly controlled cellular program of self-degradation which is activated in response of several stress in order to maintain an energetic balance (110-116). Autophagy is characterized by the formation of doublemembrane vesicles (autophagosomes) which deliver unwanted or damaged cellular material to the lysosome for degradation (111). It has been established that autophagy is activated during OIS (115-117); however, its role in the senescent phenotype is far from fully elucidated. Recent papers have demonstrated that autophagy is induced by, and at the same time contributes to the establishment of OIS through induction of the SASP via mTOR activation (TOR-autophagy spatial coupling compartment, TASCC) $(116,117)$. At the same time, autophagy inhibition has been suggested to promote senescence in certain settings (118). A recent study reconciled these findings unveiling differential behaviors of selective autophagy and general autophagy toward senescence (119). Selective autophagy is a process by which cells selectively degrade certain molecules via interaction with specific adaptors, one of which is p62 (120-122). p62 was shown to target the transcription factor GATA4 (a member of the zinc-finger family of transcription factors (123)) for degradation (119). GATA4 has been implicated in the induction of the SASP through positive regulation of NF$\mathrm{kB}$, one of the major regulators of cytokines production (119). Thus, selective autophagy may act as a senescence suppressor by downregulating senescence effectors (such as GATA4). However, senescence stimuli allow for escape of GATA4 from p62-mediated degradation and help establishing the process of general autophagy, which is a positive contributor to senescence. 


\section{Detection of Senescence in vivo}

Most of the analyses described so far have been performed mainly in cultured cells. Studying OIS in vivo is hindered by many factors, including heterogeneity in responses to oncogene activation in different tissues, expression of senescence-associated markers in non bona fide senescent cells, and limited efficacy of reagents. However, several reports described OIS in vivo.

In humans, the most natural example of OIS is represented by nevi, benign aggregations of melanocytes that exited the cell cycle $(1,3,54,124,125)$. A high proportion of melanocytes in nevi harbor activated $\mathrm{BRAF}^{\mathrm{V} 600 \mathrm{E}}$ or NRAS ${ }^{\mathrm{Q} 61 \mathrm{R}}$ proteins. Surprisingly, the same mutations have been found in malignant melanomas often at lower frequencies, suggesting that suppression of OIS is a prerequisite for tumor progression $(126,127)$. Human melanocytic nevi display several hallmark of OIS, including cell cycle arrest (assessed by absence of Ki-67 staining, a marker of cell proliferation) and increased SA- $\beta$-gal activity (54). At the same time, when stained for telomere FISH, nevomelanocytes do not display signs of telomere erosion or loss (which is an indication of age-related senescence) (54).

Transgenic mouse models for tumor initiation are also available, in which the oncogenic KrasV12 allele expression is induced by Cre recombinase in restricted tissues. Using lung- or pancreas-specific systems, researchers were able to visualize senescence in premalignant tumors using SA- $\beta-$ Gal staining and BrdU incorporation, as well as with antibodies toward OIS effectors (including p16 ${ }^{\mathrm{INK} 4 \mathrm{a}}$ and $\left.\mathrm{p} 15^{\mathrm{INK} 4 \mathrm{~b}}\right)(128,129)$.

Lower organisms such as Zebrafish (Danio rerio) and Drosophila have been used as well for studying OIS. In Zebrafish, expression of a heat shock-inducible human HRAS V12 was shown to result in robust accumulation of ROS (130). ROS induction was mediated by two orthologs of Nox4 (which is essential for ROS induction by RAS in human cells) (130). Additionally, conditional expression of human HRAS ${ }^{\mathrm{V} 12}$ induced DNA damage response (DDR) and cell arrest in a tp53-dependent fashion (131). In Drosophila instead, active Ras required concomitant induction of mitochondrial dysfunction in order to fully induce a senescent phenotype. The combination of HRas ${ }^{\mathrm{V} 12}$ and mitochondrial dysfunction was necessary to induce oxidative stress and activate c-Jun amino (N)-terminal kinase (JNK) signaling. Ras and JNK together suppressed the Hippo pathway and induced senescence (132).

Another form of senescence highly reminiscent of OIS is the therapy-induced senescence (TIS). TIS is often a consequence of anti-cancer therapy and has been shown to be induced in both tumor cells lines and in patients $(38,133-141)$. TIS and OIS share several downstream effectors and phenotypes as they both evoke a DDR. However, DNA damage is generated with different modality of actions: oncogenic induction of DNA damage arises from dNTPs depletion, ROS production and multiple firing from the same origin of replication (as described above) $(34,47,91,92,96-98,100)$; TIS-induced DNA damage is instead a result (direct or indirect) of the therapeutic agent in use, although sometimes the modality may overlap with OIS as, for example, some therapeutic agents act via depletion of nucleotide pools (142). 
Because of its cytostatic effects TIS has recently been proposed as a new strategy for cancer therapy $(38,133-141,143)$. At the same time, long-term persisting tumor senescent cells can profoundly alter the microenvironment through SASP-mediated paracrine effects and detrimentally affect neighboring cells $(8-10,88,89,113)$. In fact, it has been shown both in vitro and in vivo that factors from the SASP exacerbate malignant growth and behavior of tumor cells from several malignancies, including breast and prostate cancer as well as melanoma (88).

One of the best characterized systems for the study of TIS is a primary murine Myc-driven lymphoma model. In this model, cells have been engineered to stably over-express Bcl2 to prevent apoptosis and obtain a homogenous TIS response $(38,137)$. This allows for monitoring the effects of various genetic alterations on TIS establishment and downstream effects $(38,136,137,140,141,144)$, including knockout of $p 53$ or $p 16^{I N K 4 a}$, inactivation of DDR, and alteration of SASP factors (i.e. NF-kB and TGF- $\beta$ ).

Using the mouse model described above combined with treatment with cyclophosphamide (CTX) it has been shown that elimination of TIS lymphoma cells in vivo resulted in improved outcome, highlighting the harmful effects of long-lasting tumor senescent cells on the organism (141). TIS cells were found to have a strongly enhanced glucose uptake and ATP production through glycolytic activity, reinforcing the Warburg effect (141), and this phenomenon was linked to the high proteotoxic stress induced by the SASP $(88,145)$. At the same time, this increased glucose demand made TIS cells more sensitive to glucose uptake blockage and autophagy induction, which resulted in their caspase-dependent apoptosis, followed by tumor regression and longer-lasting therapeutic effects (141).

Finally, although senescence was first characterized in the context of aging and tumor suppression, it has been recently discovered that senescence contributes to embryonic development and tissue repair $(20,146-149)$. Mouse embryos were found to express several markers and mediators of senescence, including SA- $\beta$-gal activity and H3K9me3 $(146,147)$. Interestingly, the developmental senescence and OIS share a molecular signature which include senescence inducers $\mathrm{p} 21^{\mathrm{WAF} 1-\mathrm{CIP} 1}$ and $\mathrm{p} 15$, as well as SASP regulators (such as $C E B P / B, I G F B P 5, W N T 5 a$, and the TGF- $\beta$-pathway) $(146,147)$.

Senescence has been shown to be activated also during wounding and pathological conditions to promote healing. Cutaneous wounds induce a rapid senescence response in fibroblasts and endothelial cells and mediate release of platelet-derived growth factor AA (PDGF-AA) as part of the SASP (148). PDGF-AA induces myofibroblast differentiation to promote an efficient wound closure (148). During hepatic fibrosis, stellate cells that become senescent are more efficiently cleared by natural killer cells to limit the tissue damage (149).

\section{Concluding Remarks and Future Perspective}

The molecular processes occurring in cells undergoing oncogene-induced senescence appear to overlap with those of replicative, developmental, as well as therapy-induced senescence. While it is well appreciated that some of these same mechanisms may also contribute to tumor initiation and escape from therapy-induced death, more work needs to be done toward 
understanding which pathways and which components are responsible for it. To this end, improved methods for detection of OIS and its associated phenotypes are crucially needed. In the long run, this knowledge will potentially lead to the development of better therapeutic approaches and result in long-lasting response and increased survival of patients.

\section{References}

1. Bianchi-Smiraglia A, Nikiforov MA. Controversial aspects of oncogene-induced senescence. Cell Cycle. 2012; 11(22):4147-51. [PubMed: 23095636]

2. Gorgoulis VG, Halazonetis TD. Oncogene-induced senescence: the bright and dark side of the response. Curr Opin Cell Biol. 2010; 22(6):816-27. [PubMed: 20807678]

3. Bansal R, Nikiforov MA. Pathways of oncogene-induced senescence in human melanocytic cells. Cell Cycle. 2010; 9(14):2782-8. [PubMed: 20676024]

4. Campisi J. Senescent cells, tumor suppression, and organismal aging: good citizens, bad neighbors. Cell. 2005; 120(4):513-22. [PubMed: 15734683]

5. Courtois-Cox S, Jones SL, Cichowski K. Many roads lead to oncogene-induced senescence. Oncogene. 2008; 27(20):2801-9. [PubMed: 18193093]

6. Perez-Mancera PA, Young AR, Narita M. Inside and out: the activities of senescence in cancer. Nat Rev Cancer. 2014; 14(8):547-58. [PubMed: 25030953]

7. Salama R, Sadaie M, Hoare M, Narita M. Cellular senescence and its effector programs. Genes Dev. 2014; 28(2):99-114. [PubMed: 24449267]

8. Rodier F. Detection of the senescence-associated secretory phenotype (SASP). Methods Mol Biol. 2013; 965:165-73. [PubMed: 23296657]

9. Salminen A, Kauppinen A, Kaarniranta K. Emerging role of NF-kappaB signaling in the induction of senescence-associated secretory phenotype (SASP). Cell Signal. 2012; 24(4):835-45. [PubMed: 22182507]

10. Young AR, Narita M. SASP reflects senescence. EMBO Rep. 2009; 10(3):228-30. [PubMed: 19218920]

11. Hayflick L. The Limited in Vitro Lifetime of Human Diploid Cell Strains. Exp Cell Res. 1965; 37:614-36. [PubMed: 14315085]

12. Dimri GP, Lee X, Basile G, Acosta M, Scott G, Roskelley C, et al. A biomarker that identifies senescent human cells in culture and in aging skin in vivo. Proc Natl Acad Sci U S A. 1995; 92(20):9363-7. [PubMed: 7568133]

13. Lee BY, Han JA, Im JS, Morrone A, Johung K, Goodwin EC, et al. Senescence-associated betagalactosidase is lysosomal beta-galactosidase. Aging Cell. 2006; 5(2):187-95. [PubMed: 16626397]

14. Cristofalo VJ, Lorenzini A, Allen RG, Torres C, Tresini M. Replicative senescence: a critical review. Mech Ageing Dev. 2004; 125(10-11):827-48. [PubMed: 15541776]

15. Rodier F, Campisi J. Four faces of cellular senescence. J Cell Biol. 2011; 192(4):547-56. [PubMed: 21321098]

16. Martinez I, Almstead LL, DiMaio D. MicroRNAs and senescence. Aging (Albany NY). 2011; 3(2):77-8. [PubMed: 21304181]

17. Lafferty-Whyte K, Cairney CJ, Jamieson NB, Oien KA, Keith WN. Pathway analysis of senescence-associated miRNA targets reveals common processes to different senescence induction mechanisms. Biochim Biophys Acta. 2009; 1792(4):341-52. [PubMed: 19419692]

18. Overhoff MG, Garbe JC, Koh J, Stampfer MR, Beach DH, Bishop CL. Cellular senescence mediated by p16INK4A-coupled miRNA pathways. Nucleic Acids Res. 2014; 42(3):1606-18. [PubMed: 24217920]

19. Schraml E, Grillari J. From cellular senescence to age-associated diseases: the miRNA connection. Longev Healthspan. 2012; 1(1):10. [PubMed: 24472232]

20. Jun JI, Lau LF. The matricellular protein CCN1 induces fibroblast senescence and restricts fibrosis in cutaneous wound healing. Nat Cell Biol. 2010; 12(7):676-85. [PubMed: 20526329] 
21. Kren A, Baeriswyl V, Lehembre F, Wunderlin C, Strittmatter K, Antoniadis H, et al. Increased tumor cell dissemination and cellular senescence in the absence of beta1-integrin function. Embo J. 2007; 26(12):2832-42. [PubMed: 17541405]

22. Kortlever RM, Higgins PJ, Bernards R. Plasminogen activator inhibitor-1 is a critical downstream target of p53 in the induction of replicative senescence. Nat Cell Biol. 2006; 8(8):877-84. [PubMed: 16862142]

23. Kim KS, Seu YB, Baek SH, Kim MJ, Kim KJ, Kim JH, et al. Induction of cellular senescence by insulin-like growth factor binding protein-5 through a p53-dependent mechanism. Mol Biol Cell. 2007; 18(11):4543-52. [PubMed: 17804819]

24. Jun JI, Lau LF. Cellular senescence controls fibrosis in wound healing. Aging (Albany NY). 2010; 2(9):627-31. [PubMed: 20930261]

25. Barrett JC, Annab LA, Alcorta D, Preston G, Vojta P, Yin Y. Cellular senescence and cancer. Cold Spring Harb Symp Quant Biol. 1994; 59:411-8. [PubMed: 7587095]

26. Serrano M, Blasco MA. Putting the stress on senescence. Curr Opin Cell Biol. 2001; 13(6):748-53. [PubMed: 11698192]

27. Shay JW, Roninson IB. Hallmarks of senescence in carcinogenesis and cancer therapy. Oncogene. 2004; 23(16):2919-33. [PubMed: 15077154]

28. Prieur A, Peeper DS. Cellular senescence in vivo: a barrier to tumorigenesis. Curr Opin Cell Biol. 2008; 20(2):150-5. [PubMed: 18353625]

29. Dimauro T, David G. Ras-induced senescence and its physiological relevance in cancer. Curr Cancer Drug Targets. 2010; 10(8):869-76. [PubMed: 20718709]

30. Palmero I, Serrano M. Induction of senescence by oncogenic Ras. Methods Enzymol. 2001; 333:247-56. [PubMed: 11400340]

31. Serrano M, Lin AW, McCurrach ME, Beach D, Lowe SW. Oncogenic ras provokes premature cell senescence associated with accumulation of p53 and p16INK4a. Cell. 1997; 88(5):593-602. [PubMed: 9054499]

32. Bitler BG, Fink LS, Wei Z, Peterson JR, Zhang R. A high-content screening assay for smallmolecule modulators of oncogene-induced senescence. J Biomol Screen. 2013; 18(9):1054-61. [PubMed: 23733845]

33. Zhuang D, Mannava S, Grachtchouk V, Tang WH, Patil S, Wawrzyniak JA, et al. C-MYC overexpression is required for continuous suppression of oncogene-induced senescence in melanoma cells. Oncogene. 2008; 27(52):6623-34. [PubMed: 18679422]

34. Mannava S, Omilian AR, Wawrzyniak JA, Fink EE, Zhuang D, Miecznikowski JC, et al. PP2AB56alpha controls oncogene-induced senescence in normal and tumor human melanocytic cells. Oncogene. 2012; 31(12):1484-92. [PubMed: 21822300]

35. Chang BD, Broude EV, Fang J, Kalinichenko TV, Abdryashitov R, Poole JC, et al. p21Waf1/Cip1/ Sdi1-induced growth arrest is associated with depletion of mitosis-control proteins and leads to abnormal mitosis and endoreduplication in recovering cells. Oncogene. 2000; 19(17):2165-70. [PubMed: 10815808]

36. Acosta JC, Gil J. Senescence: a new weapon for cancer therapy. Trends in cell biology. 2012; 22(4):211-9. [PubMed: 22245068]

37. Roninson IB, Broude EV, Chang BD. If not apoptosis, then what? Treatment-induced senescence and mitotic catastrophe in tumor cells. Drug Resist Updat. 2001; 4(5):303-13. [PubMed: 11991684]

38. Schmitt CA, Fridman JS, Yang M, Lee S, Baranov E, Hoffman RM, et al. A senescence program controlled by p53 and p16INK4a contributes to the outcome of cancer therapy. Cell. 2002; 109(3): 335-46. [PubMed: 12015983]

39. Chao SK, Horwitz SB, McDaid HM. Insights into 4E-BP1 and p53 mediated regulation of accelerated cell senescence. Oncotarget. 2011; 2(1-2):89-98. [PubMed: 21399233]

40. Larsson LG. Oncogene- and tumor suppressor gene-mediated suppression of cellular senescence. Semin Cancer Biol. 2011; 21(6):367-76. [PubMed: 22037160]

41. Mallette FA, Calabrese V, Ilangumaran S, Ferbeyre G. SOCS1, a novel interaction partner of p53 controlling oncogene-induced senescence. Aging (Albany NY). 2010; 2(7):445-52. [PubMed: 20622265] 
42. Martinelli P, Bonetti P, Sironi C, Pruneri G, Fumagalli C, Raviele PR, et al. The lymphomaassociated NPM-ALK oncogene elicits a p16INK4a/pRb-dependent tumor-suppressive pathway. Blood. 2011; 117(24):6617-26. [PubMed: 21518927]

43. Ventura A, Kirsch DG, McLaughlin ME, Tuveson DA, Grimm J, Lintault L, et al. Restoration of p53 function leads to tumour regression in vivo. Nature. 2007; 445(7128):661-5. [PubMed: 17251932]

44. Xu M, Yu Q, Subrahmanyam R, Difilippantonio MJ, Ried T, Sen JM. Beta-catenin expression results in p53-independent DNA damage and oncogene-induced senescence in prelymphomagenic thymocytes in vivo. Mol Cell Biol. 2008; 28(5):1713-23. [PubMed: 18160717]

45. Xue W, Zender L, Miething C, Dickins RA, Hernando E, Krizhanovsky V, et al. Senescence and tumour clearance is triggered by p53 restoration in murine liver carcinomas. Nature. 2007; 445(7128):656-60. [PubMed: 17251933]

46. Bartkova J, Rezaei N, Liontos M, Karakaidos P, Kletsas D, Issaeva N, et al. Oncogene-induced senescence is part of the tumorigenesis barrier imposed by DNA damage checkpoints. Nature. 2006; 444(7119):633-7. [PubMed: 17136093]

47. Di Micco R, Fumagalli M, Cicalese A, Piccinin S, Gasparini P, Luise C, et al. Oncogene-induced senescence is a DNA damage response triggered by DNA hyper-replication. Nature. 2006; 444(7119):638-42. [PubMed: 17136094]

48. Denoyelle C, Abou-Rjaily G, Bezrookove V, Verhaegen M, Johnson TM, Fullen DR, et al. Antioncogenic role of the endoplasmic reticulum differentially activated by mutations in the MAPK pathway. Nat Cell Biol. 2006; 8(10):1053-63. [PubMed: 16964246]

49. Harada H, Nakagawa H, Oyama K, Takaoka M, Andl CD, Jacobmeier B, et al. Telomerase induces immortalization of human esophageal keratinocytes without p16INK4a inactivation. Mol Cancer Res. 2003; 1(10):729-38. [PubMed: 12939398]

50. Cipriano R, Kan CE, Graham J, Danielpour D, Stampfer M, Jackson MW. TGF-beta signaling engages an ATM-CHK2-p53-independent RAS-induced senescence and prevents malignant transformation in human mammary epithelial cells. Proc Natl Acad Sci U S A. 2011; 108(21): 8668-73. [PubMed: 21555587]

51. Bandyopadhyay D, Curry JL, Lin Q, Richards HW, Chen D, Hornsby PJ, et al. Dynamic assembly of chromatin complexes during cellular senescence: implications for the growth arrest of human melanocytic nevi. Aging Cell. 2007; 6(4):577-91. [PubMed: 17578512]

52. Benanti JA, Galloway DA. Normal human fibroblasts are resistant to RAS-induced senescence. Mol Cell Biol. 2004; 24(7):2842-52. [PubMed: 15024073]

53. Drayton S, Rowe J, Jones R, Vatcheva R, Cuthbert-Heavens D, Marshall J, et al. Tumor suppressor p16INK4a determines sensitivity of human cells to transformation by cooperating cellular oncogenes. Cancer Cell. 2003; 4(4):301-10. [PubMed: 14585357]

54. Michaloglou C, Vredeveld LC, Soengas MS, Denoyelle C, Kuilman T, van der Horst CM, et al. BRAFE600-associated senescence-like cell cycle arrest of human naevi. Nature. 2005; 436(7051): 720-4. [PubMed: 16079850]

55. Bueno MJ, Perez de Castro I, Malumbres M. Control of cell proliferation pathways by microRNAs. Cell Cycle. 2008; 7(20):3143-8. [PubMed: 18843198]

56. Hartig SM, Hamilton MP, Bader DA, McGuire SE. The miRNA Interactome in Metabolic Homeostasis. Trends in endocrinology and metabolism: TEM. 2015; 26(12):733-45. [PubMed: 26492831]

57. Buhagiar A, Ayers D. Chemoresistance, cancer stem cells, and miRNA influences: the case for neuroblastoma. Analytical cellular pathology. 2015; 2015:150634.

58. Loginov VI, Rykov SV, Fridman MV, Braga EA. Methylation of miRNA genes and oncogenesis. Biochemistry (Mosc). 2015; 80(2):145-62. [PubMed: 25756530]

59. Wilczynska A, Bushell M. The complexity of miRNA-mediated repression. Cell Death Differ. 2015; 22(1):22-33. [PubMed: 25190144]

60. Borgdorff V, Lleonart ME, Bishop CL, Fessart D, Bergin AH, Overhoff MG, et al. Multiple microRNAs rescue from Ras-induced senescence by inhibiting p21(Waf1/Cip1). Oncogene. 2010; 29(15):2262-71. [PubMed: 20101223] 
61. Ivanovska I, Ball AS, Diaz RL, Magnus JF, Kibukawa M, Schelter JM, et al. MicroRNAs in the miR-106b family regulate p21/CDKN1A and promote cell cycle progression. Mol Cell Biol. 2008; 28(7):2167-74. [PubMed: 18212054]

62. Hong L, Lai M, Chen M, Xie C, Liao R, Kang YJ, et al. The miR-17-92 cluster of microRNAs confers tumorigenicity by inhibiting oncogene-induced senescence. Cancer Res. 2010; 70(21): 8547-57. [PubMed: 20851997]

63. Christoffersen NR, Shalgi R, Frankel LB, Leucci E, Lees M, Klausen M, et al. p53-independent upregulation of miR-34a during oncogene-induced senescence represses MYC. Cell Death Differ. 2010; 17(2):236-45. [PubMed: 19696787]

64. Xu D, Takeshita F, Hino Y, Fukunaga S, Kudo Y, Tamaki A, et al. miR-22 represses cancer progression by inducing cellular senescence. J Cell Biol. 2011; 193(2):409-24. [PubMed: 21502362]

65. Brooks CL, Gu W. How does SIRT1 affect metabolism, senescence and cancer? Nat Rev Cancer. 2009; 9(2):123-8. [PubMed: 19132007]

66. Huang J, Gan Q, Han L, Li J, Zhang H, Sun Y, et al. SIRT1 overexpression antagonizes cellular senescence with activated ERK/S6k1 signaling in human diploid fibroblasts. PLoS One. 2008; 3(3):e1710. [PubMed: 18320031]

67. Solomon JM, Pasupuleti R, Xu L, McDonagh T, Curtis R, DiStefano PS, et al. Inhibition of SIRT1 catalytic activity increases p53 acetylation but does not alter cell survival following DNA damage. Mol Cell Biol. 2006; 26(1):28-38. [PubMed: 16354677]

68. Koutsodontis G, Tentes I, Papakosta P, Moustakas A, Kardassis D. Sp1 plays a critical role in the transcriptional activation of the human cyclin-dependent kinase inhibitor p21(WAF1/Cip1) gene by the p53 tumor suppressor protein. J Biol Chem. 2001; 276(31):29116-25. [PubMed: 11384995]

69. Tapias A, Ciudad CJ, Roninson IB, Noe V. Regulation of Sp1 by cell cycle related proteins. Cell Cycle. 2008; 7(18):2856-67. [PubMed: 18769160]

70. Ohtani N, Mann DJ, Hara E. Cellular senescence: its role in tumor suppression and aging. Cancer Sci. 2009; 100(5):792-7. [PubMed: 19302284]

71. Ruas M, Gregory F, Jones R, Poolman R, Starborg M, Rowe J, et al. CDK4 and CDK6 delay senescence by kinase-dependent and p16INK4a-independent mechanisms. Mol Cell Biol. 2007; 27(12):4273-82. [PubMed: 17420273]

72. Hansen TB, Kjems J, Damgaard CK. Circular RNA and miR-7 in cancer. Cancer Res. 2013; 73(18):5609-12. [PubMed: 24014594]

73. Memczak S, Jens M, Elefsinioti A, Torti F, Krueger J, Rybak A, et al. Circular RNAs are a large class of animal RNAs with regulatory potency. Nature. 2013; 495(7441):333-8. [PubMed: 23446348]

74. Salzman J, Gawad C, Wang PL, Lacayo N, Brown PO. Circular RNAs are the predominant transcript isoform from hundreds of human genes in diverse cell types. PLoS One. 2012; 7(2):e30733. [PubMed: 22319583]

75. Hansen TB, Jensen TI, Clausen BH, Bramsen JB, Finsen B, Damgaard CK, et al. Natural RNA circles function as efficient microRNA sponges. Nature. 2013; 495(7441):384-8. [PubMed: 23446346]

76. Wang YH, Yu XH, Luo SS, Han H. Comprehensive circular RNA profiling reveals that circular RNA100783 is involved in chronic CD28-associated CD8(+)T cell ageing. Immun Ageing. 2015; 12:17. [PubMed: 26451160]

77. Wajapeyee N, Deibler SK, Green MR. Genome-wide RNAi screening to identify regulators of oncogene-induced cellular senescence. Methods Mol Biol. 2013; 965:373-82. [PubMed: 23296672]

78. Wajapeyee N, Serra RW, Zhu X, Mahalingam M, Green MR. Oncogenic BRAF induces senescence and apoptosis through pathways mediated by the secreted protein IGFBP7. Cell. 2008; 132(3):363-74. [PubMed: 18267069]

79. Sharpless NE, Sherr CJ. Forging a signature of in vivo senescence. Nat Rev Cancer. 2015; 15(7): 397-408. [PubMed: 26105537]

80. Collado M, Serrano M. The power and the promise of oncogene-induced senescence markers. Nat Rev Cancer. 2006; 6(6):472-6. [PubMed: 16723993] 
81. Althubiti M, Lezina L, Carrera S, Jukes-Jones R, Giblett SM, Antonov A, et al. Characterization of novel markers of senescence and their prognostic potential in cancer. Cell Death Dis. 2014; 5:e1528.

82. Yang NC, Hu ML. A fluorimetric method using fluorescein di-beta-D-galactopyranoside for quantifying the senescence-associated beta-galactosidase activity in human foreskin fibroblast Hs68 cells. Anal Biochem. 2004; 325(2):337-43. [PubMed: 14751269]

83. Yang NC, Hu ML. The limitations and validities of senescence associated-beta-galactosidase activity as an aging marker for human foreskin fibroblast Hs68 cells. Exp Gerontol. 2005; 40(10): 813-9. [PubMed: 16154306]

84. Yegorov YE, Akimov SS, Hass R, Zelenin AV, Prudovsky IA. Endogenous beta-galactosidase activity in continuously nonproliferating cells. Exp Cell Res. 1998; 243(1):207-11. [PubMed: 9716464]

85. Brunk UT, Terman A. Lipofuscin: mechanisms of age-related accumulation and influence on cell function. Free Radic Biol Med. 2002; 33(5):611-9. [PubMed: 12208347]

86. Gerland LM, Peyrol S, Lallemand C, Branche R, Magaud JP, Ffrench M. Association of increased autophagic inclusions labeled for beta-galactosidase with fibroblastic aging. Exp Gerontol. 2003; 38(8):887-95. [PubMed: 12915210]

87. Georgakopoulou EA, Tsimaratou K, Evangelou K, Fernandez Marcos PJ, Zoumpourlis V, Trougakos IP, et al. Specific lipofuscin staining as a novel biomarker to detect replicative and stress-induced senescence. A method applicable in cryo-preserved and archival tissues. Aging (Albany NY). 2013; 5(1):37-50. [PubMed: 23449538]

88. Coppe JP, Desprez PY, Krtolica A, Campisi J. The senescence-associated secretory phenotype: the dark side of tumor suppression. Annu Rev Pathol. 2010; 5:99-118. [PubMed: 20078217]

89. Herranz N, Gallage S, Gil J. TORn about SASP regulation. Cell Cycle. 2015; 14(24):3771-2. [PubMed: 26697828]

90. Acosta JC, Banito A, Wuestefeld T, Georgilis A, Janich P, Morton JP, et al. A complex secretory program orchestrated by the inflammasome controls paracrine senescence. Nat Cell Biol. 2013; 15(8):978-90. [PubMed: 23770676]

91. Weyemi U, Dupuy C. The emerging role of ROS-generating NADPH oxidase NOX4 in DNAdamage responses. Mutat Res. 2012; 751(2):77-81. [PubMed: 22580379]

92. Weyemi U, Lagente-Chevallier O, Boufraqech M, Prenois F, Courtin F, Caillou B, et al. ROSgenerating NADPH oxidase NOX4 is a critical mediator in oncogenic H-Ras-induced DNA damage and subsequent senescence. Oncogene. 2012; 31(9):1117-29. [PubMed: 21841825]

93. Takai H, Smogorzewska A, de Lange T. DNA damage foci at dysfunctional telomeres. Curr Biol. 2003; 13(17):1549-56. [PubMed: 12956959]

94. Brugat T, Nguyen-Khac F, Grelier A, Merle-Beral H, Delic J. Telomere dysfunction-induced foci arise with the onset of telomeric deletions and complex chromosomal aberrations in resistant chronic lymphocytic leukemia cells. Blood. 2010; 116(2):239-49. [PubMed: 20424183]

95. Suram A, Kaplunov J, Patel PL, Ruan H, Cerutti A, Boccardi V, et al. Oncogene-induced telomere dysfunction enforces cellular senescence in human cancer precursor lesions. EMBO J. 2012; 31(13):2839-51. [PubMed: 22569128]

96. Mannava S, Moparthy KC, Wheeler LJ, Natarajan V, Zucker SN, Fink EE, et al. Depletion of deoxyribonucleotide pools is an endogenous source of DNA damage in cells undergoing oncogene-induced senescence. The American journal of pathology. 2013; 182(1):142-51. [PubMed: 23245831]

97. Aird KM, Zhang G, Li H, Tu Z, Bitler BG, Garipov A, et al. Suppression of nucleotide metabolism underlies the establishment and maintenance of oncogene-induced senescence. Cell Rep. 2013; 3(4):1252-65. [PubMed: 23562156]

98. Mannava S, Moparthy KC, Wheeler LJ, Leonova KI, Wawrzyniak JA, Bianchi-Smiraglia A, et al. Ribonucleotide reductase and thymidylate synthase or exogenous deoxyribonucleosides reduce DNA damage and senescence caused by C-MYC depletion. Aging (Albany NY). 2012

99. Liu YC, Li F, Handler J, Huang CR, Xiang Y, Neretti N, et al. Global regulation of nucleotide biosynthetic genes by c-Myc. PLoS One. 2008; 3(7):e2722. [PubMed: 18628958] 
100. Mannava S, Grachtchouk V, Wheeler LJ, Im M, Zhuang D, Slavina EG, et al. Direct role of nucleotide metabolism in C-MYC-dependent proliferation of melanoma cells. Cell Cycle. 2008; 7(15):2392-400. [PubMed: 18677108]

101. Bester AC, Roniger M, Oren YS, Im MM, Sarni D, Chaoat M, et al. Nucleotide deficiency promotes genomic instability in early stages of cancer development. Cell. 2011; 145(3):435-46. [PubMed: 21529715]

102. Gey C, Seeger K. Metabolic changes during cellular senescence investigated by proton NMRspectroscopy. Mech Ageing Dev. 2013; 134(3-4):130-8. [PubMed: 23416267]

103. Quijano C, Cao L, Fergusson MM, Romero H, Liu J, Gutkind S, et al. Oncogene-induced senescence results in marked metabolic and bioenergetic alterations. Cell Cycle. 2012; 11(7): 1383-92. [PubMed: 22421146]

104. Johmura Y, Sun J, Kitagawa K, Nakanishi K, Kuno T, Naiki-Ito A, et al. SCF(Fbxo22)-KDM4A targets methylated p53 for degradation and regulates senescence. Nat Commun. 2016; 7:10574. [PubMed: 26868148]

105. Zhu H, Ren S, Bitler BG, Aird KM, Tu Z, Skordalakes E, et al. SPOP E3 Ubiquitin Ligase Adaptor Promotes Cellular Senescence by Degrading the SENP7 deSUMOylase. Cell Rep. 2015; 13(6):1183-93. [PubMed: 26527005]

106. Bengsch F, Tu Z, Tang HY, Zhu H, Speicher DW, Zhang R. Comprehensive analysis of the ubiquitinome during oncogene-induced senescence in human fibroblasts. Cell Cycle. 2015; 14(10):1540-7. [PubMed: 25785348]

107. Chau V, Tobias JW, Bachmair A, Marriott D, Ecker DJ, Gonda DK, et al. A multiubiquitin chain is confined to specific lysine in a targeted short-lived protein. Science. 1989; 243(4898):1576-83. [PubMed: 2538923]

108. Mittal R, McMahon HT. Arrestins as adaptors for ubiquitination in endocytosis and sorting. EMBO Rep. 2009; 10(1):41-3. [PubMed: 19057574]

109. Neutzner M, Neutzner A. Enzymes of ubiquitination and deubiquitination. Essays Biochem. 2012; 52:37-50. [PubMed: 22708562]

110. Magnuson B, Ekim B, Fingar DC. Regulation and function of ribosomal protein S6 kinase (S6K) within mTOR signalling networks. Biochem J. 2012; 441(1):1-21. [PubMed: 22168436]

111. Glick D, Barth S, Macleod KF. Autophagy: cellular and molecular mechanisms. J Pathol. 2010; 221(1):3-12. [PubMed: 20225336]

112. Jung CH, Ro SH, Cao J, Otto NM, Kim DH. mTOR regulation of autophagy. FEBS Lett. 2010; 584(7):1287-95. [PubMed: 20083114]

113. Herranz N, Gallage S, Mellone M, Wuestefeld T, Klotz S, Hanley CJ, et al. mTOR regulates MAPKAPK2 translation to control the senescence-associated secretory phenotype. Nat Cell Biol. 2015; 17(9):1205-17. [PubMed: 26280535]

114. Laberge RM, Sun Y, Orjalo AV, Patil CK, Freund A, Zhou L, et al. MTOR regulates the protumorigenic senescence-associated secretory phenotype by promoting IL1A translation. Nat Cell Biol. 2015; 17(8):1049-61. [PubMed: 26147250]

115. Narita M, Young AR, Arakawa S, Samarajiwa SA, Nakashima T, Yoshida S, et al. Spatial coupling of mTOR and autophagy augments secretory phenotypes. Science. 2011; 332(6032): 966-70. [PubMed: 21512002]

116. Young AR, Narita M, Narita M. Spatio-temporal association between mTOR and autophagy during cellular senescence. Autophagy. 2011; 7(11):1387-8. [PubMed: 21799306]

117. Young AR, Narita M, Ferreira M, Kirschner K, Sadaie M, Darot JF, et al. Autophagy mediates the mitotic senescence transition. Genes Dev. 2009; 23(7):798-803. [PubMed: 19279323]

118. Gewirtz DA. Autophagy and senescence: a partnership in search of definition. Autophagy. 2013; 9(5):808-12. [PubMed: 23422284]

119. Kang C, Xu Q, Martin TD, Li MZ, Demaria M, Aron L, et al. The DNA damage response induces inflammation and senescence by inhibiting autophagy of GATA4. Science. 2015; 349(6255):aaa5612. [PubMed: 26404840]

120. Jin M, Liu X, Klionsky DJ. SnapShot: Selective autophagy. Cell. 2013; 152(1-2):368-e2. [PubMed: 23332767] 
121. Johansen T, Lamark T. Selective autophagy mediated by autophagic adapter proteins. Autophagy. 2011; 7(3):279-96. [PubMed: 21189453]

122. Shaid S, Brandts CH, Serve H, Dikic I. Ubiquitination and selective autophagy. Cell Death Differ. 2013; 20(1):21-30. [PubMed: 22722335]

123. Viger RS, Guittot SM, Anttonen M, Wilson DB, Heikinheimo M. Role of the GATA family of transcription factors in endocrine development, function, and disease. Mol Endocrinol. 2008; 22(4):781-98. [PubMed: 18174356]

124. Bauer J, Curtin JA, Pinkel D, Bastian BC. Congenital melanocytic nevi frequently harbor NRAS mutations but no BRAF mutations. J Invest Dermatol. 2007; 127(1):179-82. [PubMed: 16888631]

125. Pollock PM, Harper UL, Hansen KS, Yudt LM, Stark M, Robbins CM, et al. High frequency of BRAF mutations in nevi. Nat Genet. 2003; 33(1):19-20. [PubMed: 12447372]

126. Curtin JA, Fridlyand J, Kageshita T, Patel HN, Busam KJ, Kutzner H, et al. Distinct sets of genetic alterations in melanoma. N Engl J Med. 2005; 353(20):2135-47. [PubMed: 16291983]

127. Maldonado JL, Fridlyand J, Patel H, Jain AN, Busam K, Kageshita T, et al. Determinants of BRAF mutations in primary melanomas. J Natl Cancer Inst. 2003; 95(24):1878-90. [PubMed: 14679157]

128. Collado M, Gil J, Efeyan A, Guerra C, Schuhmacher AJ, Barradas M, et al. Tumour biology: senescence in premalignant tumours. Nature. 2005; 436(7051):642. [PubMed: 16079833]

129. Baek KH, Bhang D, Zaslavsky A, Wang LC, Vachani A, Kim CF, et al. Thrombospondin-1 mediates oncogenic Ras-induced senescence in premalignant lung tumors. J Clin Invest. 2013; 123(10):4375-89. [PubMed: 24018559]

130. Ogrunc M, Di Micco R, Liontos M, Bombardelli L, Mione M, Fumagalli M, et al. Oncogeneinduced reactive oxygen species fuel hyperproliferation and DNA damage response activation. Cell Death Differ. 2014; 21(6):998-1012. [PubMed: 24583638]

131. Santoriello C, Deflorian G, Pezzimenti F, Kawakami K, Lanfrancone L, d'Adda di Fagagna F, et al. Expression of H-RASV12 in a zebrafish model of Costello syndrome causes cellular senescence in adult proliferating cells. Dis Model Mech. 2009; 2(1-2):56-67. [PubMed: 19132118]

132. Ohsawa S, Sato Y, Enomoto M, Nakamura M, Betsumiya A, Igaki T. Mitochondrial defect drives non-autonomous tumour progression through Hippo signalling in Drosophila. Nature. 2012; 490(7421):547-51. [PubMed: 23023132]

133. Chang BD, Xuan Y, Broude EV, Zhu H, Schott B, Fang J, et al. Role of p53 and p21waf1/cip1 in senescence-like terminal proliferation arrest induced in human tumor cells by chemotherapeutic drugs. Oncogene. 1999; 18(34):4808-18. [PubMed: 10490814]

134. Chang BD, Broude EV, Dokmanovic M, Zhu H, Ruth A, Xuan Y, et al. A senescence-like phenotype distinguishes tumor cells that undergo terminal proliferation arrest after exposure to anticancer agents. Cancer research. 1999; 59(15):3761-7. [PubMed: 10446993]

135. te Poele RH, Okorokov AL, Jardine L, Cummings J, Joel SP. DNA damage is able to induce senescence in tumor cells in vitro and in vivo. Cancer research. 2002; 62(6):1876-83. [PubMed: 11912168]

136. Schmitt CA, Fridman JS, Yang M, Baranov E, Hoffman RM, Lowe SW. Dissecting p53 tumor suppressor functions in vivo. Cancer Cell. 2002; 1(3):289-98. [PubMed: 12086865]

137. Schmitt CA, Lowe SW. Apoptosis and chemoresistance in transgenic cancer models. J Mol Med (Berl). 2002; 80(3):137-46. [PubMed: 11894140]

138. Schmitt CA, Rosenthal CT, Lowe SW. Genetic analysis of chemoresistance in primary murine lymphomas. Nature medicine. 2000; 6(9):1029-35.

139. Braig M, Lee S, Loddenkemper C, Rudolph C, Peters AHFM, Schlegelberger B, et al. Oncogeneinduced senescence as an initial barrier in lymphoma development. Nature. 2005; 436(7051): 660-5. [PubMed: 16079837]

140. Jing H, Kase J, Dorr JR, Milanovic M, Lenze D, Grau M, et al. Opposing roles of NF-kappaB in anti-cancer treatment outcome unveiled by cross-species investigations. Genes Dev. 2011; 25(20):2137-46. [PubMed: 21979374] 
141. Dorr JR, Yu Y, Milanovic M, Beuster G, Zasada C, Dabritz JH, et al. Synthetic lethal metabolic targeting of cellular senescence in cancer therapy. Nature. 2013; 501(7467):421-5. [PubMed: 23945590]

142. Hosoya N, Miyagawa K. Targeting DNA damage response in cancer therapy. Cancer Sci. 2014; 105(4):370-88. [PubMed: 24484288]

143. Ewald JA, Desotelle JA, Wilding G, Jarrard DF. Therapy-induced senescence in cancer. J Natl Cancer Inst. 2010; 102(20):1536-46. [PubMed: 20858887]

144. Reimann M, Lee S, Loddenkemper C, Dorr JR, Tabor V, Aichele P, et al. Tumor stroma-derived TGF-beta limits myc-driven lymphomagenesis via Suv39h1-dependent senescence. Cancer Cell. 2010; 17(3):262-72. [PubMed: 20227040]

145. Acosta JC, O'Loghlen A, Banito A, Guijarro MV, Augert A, Raguz S, et al. Chemokine signaling via the CXCR2 receptor reinforces senescence. Cell. 2008; 133(6):1006-18. [PubMed: 18555777]

146. Storer M, Mas A, Robert-Moreno A, Pecoraro M, Ortells MC, Di Giacomo V, et al. Senescence is a developmental mechanism that contributes to embryonic growth and patterning. Cell. 2013; 155(5):1119-30. [PubMed: 24238961]

147. Munoz-Espin D, Canamero M, Maraver A, Gomez-Lopez G, Contreras J, Murillo-Cuesta S, et al. Programmed cell senescence during mammalian embryonic development. Cell. 2013; 155(5): 1104-18. [PubMed: 24238962]

148. Demaria M, Ohtani N, Youssef SA, Rodier F, Toussaint W, Mitchell JR, et al. An essential role for senescent cells in optimal wound healing through secretion of PDGF-AA. Dev Cell. 2014; 31(6):722-33. [PubMed: 25499914]

149. Krizhanovsky V, Yon M, Dickins RA, Hearn S, Simon J, Miething C, et al. Senescence of activated stellate cells limits liver fibrosis. Cell. 2008; 134(4):657-67. [PubMed: 18724938] 